\title{
Influence of Multiple Cultures on College Students' Socialist Core Values Education
}

\author{
Minghui Li \\ College of International Exchange, Bohai University, Jinzhou, 121013, China \\ liminghui0607@sina.cn
}

\begin{abstract}
Keywords: multi culture; college students; socialist core values; positive effect; impact and challenge
\end{abstract}

\begin{abstract}
Multi culture coexistence is a form of social and cultural development and prosperity, also bring huge impact to people's ideology. Multi culture socialist core education for college students has a positive effect, enriched the contents of the education of college students' values and understanding ability, open core values education of college students way of thinking, the core values education for college students provides a development space; However, multi culture education on college students' core values have impact and challenge again, different culture in different forms in front of college students, to student's thought brought impact and challenges, mainly in indifferent political beliefs, ideal concept of secular life attitude, value orientation, personalized game, relativity of moral standards, etc.
\end{abstract}

\section{Introduction}

Values is an important spiritual pillar in life and career, spiritual pursuit and intrinsic motivation, to human body needs, requirements, ideal, faith, such as closely linked together. One's social status, economic status and the ideological and political consciousness determines the values. In Chinese society, advocate and practice the socialist core values, the pursuit of the harmony between individuality and sociality. This value system from belongs to the strong vitality of marxism, on the development path of China's society, whether it improve the social public to accurate understanding of society, encourage social members to a common goal to struggle, or social cohesion force one after another great feat, the values have played an irreplaceable role in adjusting and optimizing.

In today's society in the age of multi culture blend and collide with each other, all kinds of cultures coexist and interact with each other. Various foreign ideology, life style, ethics, ideology, such as pouring into, in the traditional culture and modern culture, Oriental culture and western culture, the mainstream culture and non-mainstream culture, mass culture and elite culture, multi culture coexistence phenomenon. These cultural exchange and collision, directly affect the values of college students, for college students to offer the diversity of value selection of space and freedom, gives more rich spiritual world [1]. However, some college students ignore the traditional virtues such as collectivism, selfless dedication, tilt to the extreme individualism, the values appear contradictions and confusion, even on the code of conduct as "misconduct" state. College students are the future of our motherland and hope, is the main force of construction socialist cultural power, cultural pluralism and multiculturalism in the new situation, to strengthen college students' values education, enhance the level of their ideological and moral and value orientation is a very urgent strategic task, related to the comprehensive development of college students and social harmony and stability, more related to the future of the country and people. 


\section{Multi Culture and Its Characteristics}

Multi culture refers to the human society is more and more complicated, the more information circulation to developed, the update transformation of culture is increasingly accelerated, all kinds of cultural development is faced with different opportunities and challenges, new culture also emerge in endlessly. Under the modern complex social structure, the inevitable demand for a variety of cultural services in the development of the society, the cultural services in the development of the society, it has created the diversity of culture, is the complicated social background of multi-culture. In today's highly development of science and technology, the human world is a big family, the earth has become a "global village", people living on the earth, communication is more and more close, cherish peace is the common desire of the people of the world and voice. Different traditional culture, lifestyle, ideology, religion, constitute a natural relations of equality of harmony. Achieve different relationship with various ethnic groups, multi culture each other mutual respect, mutual care, respect each other, mutual cooperation, common to create multiple mankind civilization of social ideal, this is the goal of the common people all over the world yearn. Multi culture communication way as shown in Fig. 1.

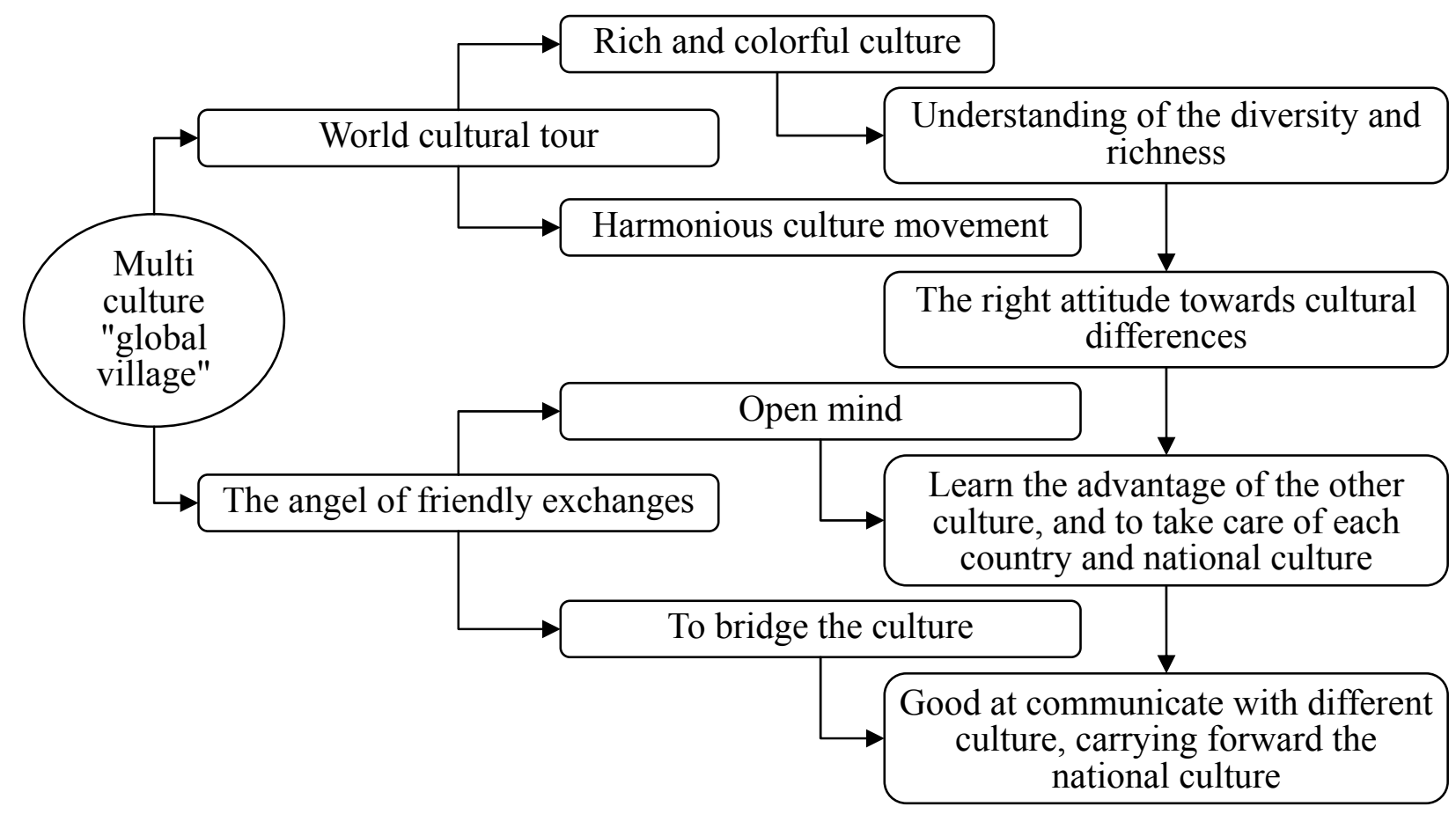

Fig. 1. Ways of Communication on Multiple Cultures

World multi culture is a civilization of the human knowledge of common culture produced a whole culture, the people of different ethnic groups is an interdependent community life. Multi culture has the following characteristics [2-7]:

(1) Diversity."Cultural diversity" is defined as a group and a variety of different forms of society so as to show its culture. These forms between the internal and inheritance. Cultural diversity is not only reflected in the human cultural heritage through rich and colorful cultural forms to express, promote and develop a variety of ways, also in using a variety of ways and techniques for the art of creation, production, dissemination, sale and consumption of a variety of ways. Cultural diversity is the basic feature of human society, also is the important power the progress of human civilization. Emphasis on cultural diversity in the community, ethnic and national sustainable development plays an important role.

(2) Inheritance. Human breeding, forward, also continuous culture, from generation to generation. Inheritance is the foundation of culture, if there is no inheritance, there would be no culture at all. In the process of the history of cultural development, each new phase at the same time, a rejection of 
previous stage must absorb all progress of its content, and human had made all the outstanding achievements.

(3) The difference. Cultural differences refers to the similarities and differences from area to area, regional differences as a result of the peculiar cultural similarities and differences between. Describe the various indicators of cultural differences there are five: power distance, uncertainty avoidance index, individualism versus collectivism, masculine versus feminility, long vs short term orientation. There are a lot of differences between different culture, and the differences are rooted in the minds of the people, it is difficult to change easily. The history of cultural differences is by the national tradition and the different social development process, performance in all aspects of social culture.

(4) Complementary to each other. Cultural difference is not the source of conflict, but the premise of complementary. Correctly understanding the differences of culture, the understanding of cultural diversity and relativity, enhance cultural compatibility and complementarity, weaken or eliminate exclusivity, complement each other between different culture. Cultural complementary principle is an important concept of the world's different cultures coexist peacefully. The more the opposite sex, heterogeneous culture, complementary is stronger also. Any a kind of culture in the long historical development, is not self sealing, but to protect their own characteristics in the interaction, complement each other in competition and comparison, in seeking common ground while putting aside differences, common development.

(5) Cohesion. Different cultures can coexist in a joint in the body, its important reason lies in various culture not only admit the differences of each other, more important is also found between each other in common, namely between different cultures can learn from each other. In this sense, the essence of the multi culture purpose is not to highlight a certain culture, but rather to provide processing mutual relationships between two or more cultural attitudes and methods.

(6) Nationality. Culture is always rooted in the nation, born with the development of the nation. The culture of a nation, a nation of different ethnic groups have different national culture. National culture is one of the forms of ethnic groups, all ethnic groups in the long-term historical development process of natural creation and development, with the national characteristics of culture. National culture is extremely rich in terms of its connotation, in terms of its form is varied. Are often national the higher the level of social productive forces, and the long history, its cultural connotation is rich, culture spirit is strong, so their nationality is more prominent, the more distinct.

\section{Positive Effect of Multiple Culture on College Students' Socialist Core Values Education}

Multi culture open expansion of the college students' horizons, enrich the college students' thoughts, add new meaning to the college students' values education, socialist core education for college students has a positive effect, mainly manifested in the following respects [8-10]:

(1) To promote the formation of college students' mainstream values. Mainstream values based on the real life, is a fierce value conflict apparent values, timely and reality, have a huge role on social development, and is widely accepted and followed. The contemporary Chinese mainstream values is the development, harmony, justice, efficiency and innovation. The ideological characteristics of college students reflects the social and historical background of The Times, in the period of social transformation, college students the concept of change, and promote the social progress. An honest and trustworthy business become the value choice of college students accepted by most of the college students, the main body consciousness enhancement among college students is more apparent, diligent to become the new developing trend of college students.

(2) For the formation of the values of college students on the development of reference. Since reform and opening up, with the aid of various channels to infiltrate the rising number of elements of western culture in China. In this case, multi culture system on the one hand, made the learning of the values of contemporary college students form more diverse, more rich content, also for the formation and development of its values provide more reference, can be on the basis of the existing values continue to choose the development direction of the future. Not only could improve the ability of college students' value choice, but also make itself become a pluralistic culture system, 
college students under the impact of the multi-cultural values, to emancipate the mind, horizons, renew the idea, and understand the purpose of society.

(3) Make the content and form of college students' values education expanded. Multi culture social environment to broaden the students' field of vision, help college students to the east and the west cultural exchange, reference and comparison, to a certain extent, enhance students of social discrimination and understanding ability. College students pay close attention to values, the ideology and the exposure degree and sensitive degree of ideological and political phenomenon, in depth, breadth goes far beyond any of The Times, values education along with the changes in the development of the concept of education in colleges and universities to get rich and the development, the content of the education is also expanding due to the diversity of culture. Education forms in fulfilling education theory development and innovation.

(4) Core values education for college students provides a new space for development. Along with the speeding up of economic globalization, a common human practice activity expanding, national economic system, operation mode, increasing the generality of the social production, countries in economic activities in accordance with the rules of the same or similar activities, to reach consensus in understanding each other, which makes the development of national culture cannot be isolated, alone. In the conflict and blending of the multi culture, core values are more diverse knowledge and theoretical study of content and form, make the ideological and political education more targeted for a variety of values to guide, attract college students actively participate in the core values of knowledge learning, can obtain good education effect.

(5) For the ideological and political education work has brought new opportunities. Traditional ideological and political education model has been difficult to adapt to the development of the situation. Now young college students, the life condition is superior, from an early age to accept all kinds of culture, learning ability is strong, a very convenient way to get the information and extensive. If you still insist on previous education mode, not only can't receive good education effect, may cause strong negative feelings. Therefore, for education workers, to understand the multi culture, keep up with the trend of The Times, the renewal education idea, in the perspective of the multi-cultural explore new train of thought of contemporary college students' values education is a priority.

\section{Impact and Challenge of Multiple Culture on College Students' Socialist Core Values Education}

Rich culture to present in front of the college students are different with different morphology, due to the college students psychological and ideological immature and the limitations of social practice, to bring the thoughts of the modern college students the impact and challenges, mainly manifested in the following respects $[11,12]$ :

(1) Change the way of life, have impact on the value orientation. In today's increasingly global, and the ensuing influx of foreign culture, for western values and way of life a serious impact on the value orientation of college students. Pouring into lots of new ideas, new ideas, make the value orientation of college students is plural. For many complex cultural phenomenon, because of the lack of certain discrimination, not dialectical thinking, reasonable sublation, leading to excessive advocating western culture, some college students and exclusive national culture, negative culture and exclude mainstream culture. Selfish, utilitarian, enjoyment and exclusive devotion, dedication, thrift, serious can affect the formation of the correct values.

(2) The ideal belief crisis, political consciousness indifference. Multi culture strongly impact college students come into contact with all sorts of culture, and even conflicting beliefs choice, minority college students lose myself, lost in thought consciousness. Performance on the political belief, some people can not resist the temptation of western values, lose the mainstream ideology, advancing showed suspicion and even negative marxism-leninism and Mao Zedong Thought, Dengxiaoping theory, especially the performance on the mistrust of the ruling party. In study and life of the mainstream of the original ideal faith, which is under the multi culture conflict serious 
belief crisis during the period of social transformation. The problem solving is not good, can make college students lost sense of direction and motivation.

(3) The network culture shock, the complexity of values education. Rich network culture with unique charm, make more and more college students. But the network as a media tool, also brings negative effect. Network transmission of information transfer across time and space, spread across culture, information liberalization and regulation across national borders, netizens discrete concealment, communication, etc. Western culture infiltration through the network to the ideological convenient, western spiritual and cultural products and values within reach, many college students involuntarily affected, it played down the university students' socialism, collectivism values, and broke the value of the education system, make the values to the differentiation of combination, which has the characteristics of contradiction, diversity and instability.

(4) The complex social environment, values to harder. Environment is a kind of important education resources, the environment is vital to make change people's thoughts and actions. The development of the socialist market economy, make the country prosperous situation. But people are constantly chasing interests and the pursuit of efficiency, easy to produce quick buck thought and the idea of mercenaries, on college students' education and dedication of the collectivist values education is great challenge. China and in the special period of social transformation at the same time, society appear a series of phenomenon, seriously affecting the college students understanding about justice and about honesty friendly convinced, about equal harmonious question, is not conducive to college students cultivate socialist core values.

(5) The value evaluation system diversity, college students. With the deepening of opening to the outside world and the development of market economy, the traditional judgment standard is one yuan values by the impact and challenges, presents the characteristics of diversity and pluralism. Values education in yuan evaluation system is gradually updated by multi culture phenomenon, which has the function of control part of the traditional values have been weakened. Contemporary university biological in conflicts of values, make choices and trade-offs, very easy to get lost in the choice of a variety of values and many inextricable dilemma, thus appeared values pursuit aloof and indifferent.

\section{Conclusion}

To strengthen college students' core values education, is the current urgent task of the ideological and political education in colleges and universities. Contemporary college students as the backbone of the country and the future builders and successors to the cause of socialism, is gradually maturing in psychological group, faced with a variety of ideological culture, values, such as collision and impact, manifest diversified value orientation, ideological and political education face unprecedented challenges. Therefore, comprehensive study and analysis of present situation of contemporary college students' values and characteristics, on core values as the breakthrough point to strengthen college students' core values education, with scientific values to guide contemporary college students set up core values, the characteristic of patriotism is become a subject to be solved in colleges and universities. Through the multi culture education on college students' socialist core values affect in-depth analysis, for the college students' socialist core values education theory and the practice foundation.

\section{Acknowledgement}

This work is supported by social science fund project of Liaoning province (L15BSZ021): Cultivation Strategy on College Students' Socialist Core Values in Multicultural Perspective 


\section{References}

[1] Q. Z. Tang, "Thinking of contemporary college students' values in the view of multi culture," Education and Vocation, vol. 96, no. 8, pp. 56-57, 2012.

[2] X. Wang, "The Understanding of Multicultural Education and Its Uniqueness in China in the Time of Globalization," Global Education, vol. 41, no. 6, pp. 60-65, 2012.

[3] H. Zhao, "On the connotation and characteristics of multi culture in Xinjiang," The Border Economy and Culture, vol. 12, no. 5, pp. 38-39, 2015.

[4] Y. Z. Zhao, "Cultural industry, market logic and cultural diversity: the theory and practice of sustainable development of public culture (on)," Journalistic University, vol. 26, no. 4, pp. 1-7, 2006.

[5] Y. X. Ba, "Theoretical analysis national culture and regional cultural differences," Journal of China Three Gorges University (Humanities \& Social Sciences), vol. 36, no. 2, pp. 95-98, 2014.

[6] X. L. He, "The difference and complementarity between Chinese and Western culture," Thinking, vol. 37, no. 1, pp. 98-105, 2011.

[7] M. Y. La, "Research on the reconstruction of national culture in the contemporary context," Social Science Research, vol. 35, no. 1, pp. 202-206, 2013.

[8] L. N. Qi, "Reflection and Path Innovation of College Students' value education in multicultural field," Higher Agricultural Education, vol. 31, no. 3, pp. 40-42, 2014.

[9] W. L. Zheng, "On the value of contemporary college students under the multicultural background," Educational Review, vol. 31, no. 1, pp. 21-23, 2015.

[10] X. C. He, X. Chen, "Research review on college students' socialist core values education under the multicultural background," Education Exploration, vol. 34, no. 3, pp. 30-31, 2014.

[11] S. L. He, "Some problems and Thoughts on the translation of Chinese cultural classics," School party construction and Ideological Education, vol. 31, no. 19, pp. 25-26, 2013.

[12] J. B. Yang, J. T. Liu, "Innovation of University Students' Values Education under a Multi cultural Background," Journal of Wuhan University of Technology(Social Sciences Edition), vol. 26, no. 3, pp. 469-472, 2013. 